\title{
PENGARUH EFIKASI DIRI DAN LOKUS KENDALI (LOCUS OF CONTROL) TERHADAP PRESTASI BELAJAR MATEMATIKA
}

\author{
ANGGI AJENG WIDYANINGGAR \\ naftalena_21ap05@yahoo.co.id \\ Program Studi Pendidikan Matematika, Fakultas Teknik, Matematika, dan IPA \\ Universitas Indraprasta PGRI
}

\begin{abstract}
Abstrak. Tujuan dari penelitian ini adalah untuk menganalisa pengaruh efikasi diri dan lokus kendali terhadap prestasi belajar Matematika. Metode penelitian yang digunakan adalah survei. Sampel berukuran 100 orang peserta didik SMAN Reguler di Jakarta Timur yang dipilih secara acak. Pengumpulan data dilaksanakan dengan teknik penyebaran angket dan tes materi semester genap kelas X. Analisis data dengan teknik analisis jalur. Uji statistik dipergunakan uji-t dan bantuan SPSS. Dari hasil penelitian ditemukan bahwa: (1) Tidak ada pengaruh secara langsung efikasi diri terhadap lokus kendali dengan $t_{\text {hitung }}=0,8376<t_{\text {tabel }}=1,98$; (2) Terdapat pengaruh secara langsung efikasi diri terhadap prestasi belajar Matematika dengan $t_{\text {hitung }}=2,3148>t_{\text {tabel }}=1,98$; (3) Tidak ada pengaruh secara langsung lokus kendali prestasi belajar Matematika dengan $\mathrm{t}_{\text {hitung }}=1,8724<\mathrm{t}_{\text {tabel }}=1,98$; (4) Tidak ada pengaruh secara tidak langsung efikasi diri terhadap prestasi belajar Matematika melalui lokus kendali dengan $\mathrm{t}_{\text {hitung }}=-0,155<\mathrm{t}_{\text {tabel }}=$ 1,98 .
\end{abstract}

Kata kunci: efikasi diri, lokus kendali, prestasi belajar matematika

\begin{abstract}
The purpose of this study was to analyze the influence of self-efficacy and locus of control on achievement of learning Mathematics. The method used was a survey. The sample size of 100 students in East Jakarta Regular SMAN randomly selected. Data collection is carried out by questionnaire and test engineering materials semester class X. Data analysis with path analysis techniques. The statistical test used t-test and SPSS. From the results of the study found that: (1) There is no direct effect of self-efficacy to locus of control with $\mathrm{t}_{\text {count }}=0.8376<\mathrm{t}_{\text {table }}=1.98$; (2) There is a direct effect of selfefficacy to learning achievement Mathematics with $\mathrm{t}_{\text {count }}=2.3148<\mathrm{t}_{\text {table }}=1.98$; (3) There is no direct effect of locus of control to learning achievement Mathematics with $\mathrm{t}_{\text {count }}=$ $1.8724<\mathrm{t}_{\text {table }}=1.98$; (4) There is no direct effect of self-efficacy to to learning achievement Mathematics through locus of control with $\mathrm{t}_{\text {count }}=-0.155<\mathrm{t}_{\text {table }}=1.98$.
\end{abstract}

Keywords: self-efficacy, locus of control, learning achievement Mathematics.

\section{PENDAHULUAN}

Sesuai dengan perkembangan zaman seperti sekarang ini kemajuan suatu Negara tidak terlepas dari kemajuan ekonomi Negara tersebut. Sedangkan perkembangan dan kemajuan ekonomi suatu Negara tidak lepas dari perkembangan pendidikan di Negara tersebut. Seperti kemerosotan ekonomi yang terjadi di Eropa saat ini maka banyak Negara yang mulai membenahi system pendidikan yang ada. Berbicara mengenai pendidikan di Negara maju maka berbanding terbalik dengan pendidikan di Indonesia. Mengenai Pendidikan di Indonesia yang terlintas dibenak kita adalah kurang berkembang dan banyaknya kontroversi yang menyangkut masalah pendidikan. Selain itu kebanyakan penduduknya kurang memiliki kesadaran akan pentingnya pendidikan. Hal tersebut terlihat dari masih besarnya persentase buta huruf dan anak putus sekolah di Indonesia saat ini. 
Untuk menciptakan pendidikan yang berkualitas tidak hanya mengandalkan pemerintah melainkan dibutuhkan dukungan dari berbagai pihak. Dalam hal ini adalah peserta didik sebagai objek, guru sebagai pendidik dan masyarakat sebagai faktor pendukung terbesar. Akan tetapi masih ditemukan masing-masing faktor tidak berjalan seperti semestinya. Sekolah dimana kegiatan proses belajar mengajar berlangsung merupakan tempat seorang anak atau peserta didik menghabiskan sebagian besar waktu mereka. Peserta didik sebagai objek pendidikan merupakan individu yang kompleks. Dikatakan kompleks karena setiap individu tidaklah sama, setiap individu mempunyai sifat, watak, perilaku maupun karakter yang berbeda-beda. Dan dalam proses perkembangannya banyak hal yang dapat mempengaruhi maupun dapat merubah karakter setiap individu. Bukan hanya proses perkembangan seorang individu mudah terpengaruh oleh hal-hal dari luar tetapi juga dalam proses belajar.

Proses belajar merupakan proses yang paling penting dalam kegiatan pembelajaran. Karena kondusif atau tidaknya proses belajar menjadi penentu prestasi belajar yang didapatkan. Dalam prosesnya seseorang memerlukan kedisiplinan, motivasi, kepercayaan diri, minat, bakat, kreatifitas, efikasi diri, locus of control dan faktor-faktor lain yang dapat mendukung proses belajar. Walau ada lebih banyak lagi faktor penghambat yang muncul dari dalam maupun luar diri individu atau peserta didik. Dari semua faktor yang diperlukan oleh individu maupun peserta didik diatas mungkin ada beberapa istilah yang masih belum dikenal oleh khalayak umum. Beberapa faktor yang baru-baru ini sering muncul adalah efikasi diri dan locus of control. Tidak jauh berbeda dengan faktor pendukung lainnya efikasi diri dan locus of control merupakan hal yang terdapat dalam diri setiap manusia.

Kesulitan yang dialami peserta didik biasanya pada mata pelajaran tertentu seperti Matematika, Fisika, Kimia maupun Biologi. Banyak hal yang menjadi penyebab kesulitan peserta didik baik dari dalam diri peserta didik maupun dari luar. Seperti yang diungkapkan oleh beberapa peserta didik tingkat SMA bahwa kesulitan yang mereka alami karena kurang motivasi dari guru, sikap guru didalam kelas, sulitnya materi,metode pengajaran, banyaknya rumus yang harus dihafal dan masih banyak lagi. Dari berbagai kesulitan itu telah banyak hal yang dilakukan oleh pemerintah mulai dari perubahan kurikulum yang tahun 2013 ini akan mulai dilaksanakan, uji kompetensi guru, peningkatan kesejahteraan guru untuk memberikan semangat pada guru-guru agar lebih meningkatkan kinerjanya, memberikan pengenalan dan pengajaran tentang metodemetode dan masih banyak lagi.

Prestasi belajar merupakan proses yang dialami oleh peserta didik dalam proses kegiatan belajar yang berhubungan dengan taraf keberhasilan peserta didik dalam proses pembelajaran. Banyak hal yang mempengaruhi prestasi belajar mulai dari motivasi, kedisiplinan, minat, kreatifitas, sikap dan lain-lain. Namun, apakah efikasi diri dan locus of control mempengaruhi prestasi belajar peserta didik?

Berdasarkan latar belakang tersebut di atas maka penulis tertarik untuk melakukan penelitian dengan judul "Pengaruh efikasi diri dan lokus kendali (locus of control) terhadap prestasi belajar matematika. (Survey pada peserta didik SMAN Reguler di Jakarta Timur)".

\section{TINJAUAN PUSTAKA}

\section{Prestasi Belajar Matematika}

Setiap manusia dalam hidupnya tidak pernah berhenti untuk belajar. Karena belajar merupakan kewajiban bagi umat manusia dari membuka mata sampai mata tertutup (meninggal). Belajar yang dimaksud adalah belajar dari semua hal baik yang didapatkan dalam dunia pendidikan maupun dalam pengalaman hidup. Menurut 
Whittaker dalam Djamarah (2001: 20), belajar adalah proses dimana tingkah laku ditimbulkan atau diubah melalui latihan atau pengalaman.

Menurut Cronchbach (Djamarah, 2001: 21), belajar adalah suatu aktivitas yang ditunjukkan oleh perubahan tingkah laku sebagai hasil dari pengalaman. Seperti menurut Slameto (2003: 2), belajar ialah suatu proses usaha yang dilakukan seseorang untuk memperoleh suatu perubahan tingkah laku yang baru secara keseluruhan, sebagai hasil pengalamannya sendiri dalam interaksi dengan lingkungannya. Perubahan yang terjadi dalam diri seseorang banyak sekali baik sifat maupun jenisnya karena itu sudah tentu setiap perubahan dalam diri seseorang merupakan perubahan dalam arti belajar.

Menurut Syah (2005: 87), belajar adalah kegiatan yang berproses dan merupakan unsur yang sangat fundamental dalam menyelenggarakan setiap jenis dan jenjang pendidikan. Ini berarti bahwa hasil atau gagalnya pencapaian tujuan pendidikan itu amat bergantung pada proses yang dialami peserta didik. Menurut Kingskey dalam Djamarah (2001: 22), belajar adalah proses dimana tingkah laku dirubah atau dimunculkan melalui praktek atau latihan. Menurut Gagne dalam Djamarah (2001: 22), belajar adalah suatu proses untuk memperoleh motivasi dalam pengetahuan, keterampilan, kebiasaan dan tingkah laku. Menurut Slameto (2003: 2), belajar adalah suatu proses usaha yang dilakukan seseorang untuk memperoleh suatu perubahan tingkah laku yang baru secara keseluruhan, sebagai hasil pengalamannya sendiri dalam interaksi dengan lingkungannya.

Berdasarkan beberapa pendapat ahli di atas dapat disimpulkan bahwa belajar adalah suatu proses usaha yang dilakukan seseorang untuk memperoleh suatu perubahan tingkah laku yang baru secara keseluruhan yang berupa perubahan kemampuankemampuan baik kognitif, senso-motorik maupun dinamik-efektif, sebagai hasil penglamannya sendiri dalam interaksi dengan lingkungan.

Menurut Syah (2005: 141), prestasi belajar adalah tingkat atau taraf keberhasilan peserta didik dalam melaksanakan pembelajaran yang telah ditetapkan dan diberikan kepadanya sesuai dengan tingkat kemampuannya. Menurut Sudjana (1999: 22), prestasi belajar adalah beragam kemampuan yang dimiliki peserta didik setelah ia mengalami pengalaman belajar. Menurut Mulyana (2006: 190), prestasi belajar adalah hasil interaksi berbagai faktor baik pribadi maupun lingkungan. Sedangkan menurut Chaplin (2002: 6), prestasi belajar adalah satu tingkat khusus dan kesuksesan karena mempelajari tugas-tugas, atau tingkat tertentu dari kecakapan/keahlian dalam tugas-tugas sekolah atau akademis. Berdasarkan teori Taksonomi Bloom prestasi belajar dalam rangka studi dicapai melalui tiga kategori ranah antara lain kognitif, afektif, psikomotor

Prestasi belajar adalah kemampuan yang diperoleh anak melalui kegiatan belajar. Belajar itu sendiri merupakan suatu proses dari seseorang yang berusaha untuk memperoleh suatu bentuk perubahan perilaku yang bersifat menetap. Dalam kegiatan belajar yang terprogram dan terkontrol yang disebut kegiatan pembelajaran atau kegiatan instruksional, guru telah menetapkan tujuan pembelajaran, tujuan itulah yang harus dicapai oleh siswa. Siswa yang berprestasi dalam belajar adalah siswa yang berhasil mencapai tujuan-tujuan pembelajaran. Dari hasil pencapaian tujuan pembelajaran itulah kemudian terjadi perubahan tingkah laku pada diri siswa.

Menurut Myklebust (Alisah, 2007: 252), Matematika adalah bahasa simbolis yang berfungsi praktisnya untuk mengekspresikan hubungan-hubungan kuantitatif keruangan sedangkan fungsi teoritisnya adalah untuk memudahkan berfikir. Sedangkan menurut Lerner (Alisah, 2007: 252), Matematika disamping bahasa simbolis juga merupakan bahasa universal yang memungkinkan manusia memikirkan, mencatat, dan mengkomunikasikan ide mengenai elemen dan kuantitas. 
Matematika adalah suatu cara untuk menemukan jawaban terhadap masalah yang dihadapi manusia, suatu cara menggunakan informasi, menggunakan pengetahuan tenatang bentuk dan ukuran, menggunakan pengetahuan tentang bentuk dan ukuran, menggunakan pengetahuan tentang menghitung. Menurut Paling (Alisah, 2007: 252), Matematika merupakan ilmu universal yang mendasari perkembangan teknologi modern, mempunyai peran penting dalam berbagai disiplin dan memajukan daya pikir manusia. Perkembangan pesat di bidang teknologi informasi dan komunikasi dewasa ini dilandasi oleh perkembangan matematika di bidang teori bilangan, aljabar, analisis, teori peluang dan matematika diskrit. Matematika merupakan bidang studi yang dipelajari oleh semua siswa dari SD sampai SMA bahkan perguruan tinggi. Sesuai dengan pernyataan Cornelius (Alisah, 2007: 253) alasan matematika perlu diajarkan karena:

1) Sarana berpikir yang jelas dan logis

2) Sarana untuk memecahkan masalah kehidupan sehari-hari.

3) Sarana mengenali pola hubungan dan generalisasi pengalaman.

4) Sarana untuk mengembangkan kreativitas

5) Sarana untuk meningkatkan kesadaran terhadap perkembangan budaya.

Dari seluruh pendapat ahli di atas dapat disimpulkan bahwa prestasi belajar matematika adalah perubahan tingkah laku peserta didik dengan tingkat atau taraf keberhasilan tertentu dalam melaksanakan pembelajaran tentang materi dan esensi pelajaran matematika. Perubahan ini berupa pemahaman terhadap pencacahan, perhitungan, pengukuran dan pengkajian sistematis konsep-konsep matematika dan kemampuan menggeneralisasikan berbagai bentuk pengetahuan setelah memperoleh pengalaman belajar matematika.

Untuk mengetahui seberapa jauh peserta didik dapat menguasai pelajaran dan tugas-tugas yang diberikan oleh guru, tes prestasi belajar bermanfaat untuk peserta didik dengan tujuan peserta didik dapat mengukur sejauh mana peserta didik tersebut menguasai materi yang telah diberikan. Selain itu juga sebagai masukan bagi para pengajar apakah materi yang disampaikan sudah dipahami oleh peserta didik.

\section{Efikasi Diri}

Orang bertingkah laku dalam situasi tertentu tergantung kepada resiprokal antara lingkungan dengan kondisi kognitif, khususnya faktor kognitif yang berhubungan dengan keyakinannya bahwa dia mampu atau tidak mampu melakukan tindakan yang memuaskan. Efikasi diri pertama kali diungkapkan oleh Bandura. Menurut Bandura dalam Alwisol (2009: 287), efikasi diri atau Self Effication adalah keyakinan atau harapan diri. Sedangkan harapan hasilnya adalah ekspektasi hasil.

Efikasi diri berhubungan dengan keyakinan bahwa diri memiliki kemampuan melakukan tindakan yang diharapkan. Efikasi adalah penilaian diri, apakah dapat melakukan tindakan yang baik atau buruk, tepat atau salah, bisa atau tidak bisa mengerjakan sesuai dengan yang dipersyaratkan. Efikasi tidak sama dengan aspirasi (citacita) karena aspirasi menggambarkan sesuatu yang ideal yang seharusnya dapat dicapai sedangkan efikasi menggambarkan penilaian tentang kemampuan diri.

Sedangkan ekspektasi hasil adalah perkiraan atau estimasi diri bahwa tingkah laku yang dilakukan diri itu akan mencapai hasil tertentu. Jika digambarkan seorang anak mempunyai ekspektasi efikasi yang tinggi untuk mendapatkan peringkat pertama dan nilai matematika 100. Namun, ekspektasi hasilnya bisa rendah karena prestasi belajar sangat tergantung kepada ketekunan dan kerja keras peserta didik itu sendiri dan faktorfaktor lain yang berpengaruh. Efikasi diri atau keyakinan kebiasaan diri dapat diperoleh, diubah, ditingkatkan atau diturunkan, melalui salah satu atau kombinasi empat sumber, (Alwisol, 2009: 287) yaitu: 


\section{Pengalaman Performansi (performance accomplishment)}

Adalah prestasi yang pernah dicapai pada masa yang telah lalu. Sebagai sumber, performansi masa lalu menjadi pengubah efikasi diri yang paling kuat pengaruhnya. Pengalaman keberhasilan sangat mempengaruhi efikasi, dapat diambil garis besar bahwa keberhasilan meningkatkan efikasi sedangkan kegagalan akan menurunkannya. Semakin kepercayaan terhadap efikasi personal seseorang meningkat, maka performanya akan semakin baik. Namun demikian, keberhasilan dan kegagalan tidak langsung menghasilkan kenaikan dan penurunan terhadap efikasi diri. Perubahan pada efikasi dihasilkan dari perubahan proses kognitif yang didapat dari pemahaman terhadap kapabilitas yang mereka miliki setelah keberhasilan atau kegagalan yang dialami dievaluasi.

2. Pengalaman Vikarius (vicarious experience)

Diperoleh melalui model sosial. Efikasi akan meningkat ketika mengamati keberhasilan orang lain, sebaliknya efikasi akan menurun jika mengamati orang yang kemampuannya kira-kira sama dengan dirinya ternyata gagal. Kapabilitas seseorang tidak hanya dapat dipelajari melalui pengalaman-pengalaman keberhasilan yang telah dicapai. Memperbandingkan pengalaman pribadi dengan penglaaman orang lain yang memiliki kemiripan dapat membentuk efikasi diri pada individu. Oleh karena itu seberapa mirip model dengan individu mempengaruhi tingkat efikasi yang dicapai. .

3. Persuasi Sosial (social persuation)

Efikasi juga dapat diperoleh, diperkuat atau dilemahkan melalui persuasi sosial. Dampak dari sumber ini terbatas, tetapi pada kondisi yang tepat persuasi dari orang lain dapat mempengaruhi efikasi diri.. Informasi yang didapat dari luar dapat meningkatkan keyakinan akan kemampuan diri seseorang. Seseorang yang diberi keyakinan dari luar akan menunjukan usaha yang lebih besar dibandingkan yang tidak dan juga dapat menghilangkan ketidak percayaan terhadap kemampuan diri dan kerentanan diri ketika masalah muncul. Persuasi sosial pada diri seseorang menghasilkan performa, yang pada kelanjutannya akan membutuhkan umpan balik kembali.

4. Pembangkitan Emosi (emotionall physiological states)

Keadaan emosi yang mengikuti suatu kegiatan akan mempengaruhi efikasi di bidang kegiatan itu misalnya dalam proses belajar. Jika emosi seseorang sedang labil maka efikasi yang dimiliki akan sulit untuk dinaikkan atau dikuatkan. Namun, jika emosi seseorang sedang semangat maka efikasi yang muncul akan semakin meningkat. Persuasi sosial memerankan peran dalam menguatkan penilaian diri terhadap kapabilitas personal individu. Informasi yang didapat dari luar dapat meningkatkan keyakinan akan kemampuan diri seseorang. Seseorang yang diberi keyakinan dari luar akan menunjukan usaha yang lebih besar dibanding yang tidak dan juga dapat menghilangkan ketidak percayaan terhadap kemampuan diri dan kerentanan diri ketika masalah muncul. Persuasi sosial pada diri seseorang menghasilkan performa, yang pada kelanjutannya akan membutuhkan umpan balik kembali.

Perkembangan Efikasi dalam diri manusia berkembang sesuai dengan masa perkembangan manusia. Sesuai dengan masa perkembangannya, manusia diberikan beban tanggung jawab perkembangan yang bertahap, semakin tinggi semakin sulit. Oleh karena itu, efikasi dalam diriseseorang pun tidak akan statis, efikasi dapat berkurang maupun bertambah sesuai denganbagaimana individu melakukan evaluasi terhadap setiap fase kehidupan yang telah dijalaninya. Menurut Bandura dalam Alwisol (2009: 287), sumber pengontrol tingkah laku adalah respirokal antara lingkungan, tingkah laku dan pribadi. Efikasi merupakan variable pribadi yang penting, yang kalau digabung dengan 
tujuan-tujuan spesifik dan pemahaman mengenai prestasi akan menjadi penentu tingkah laku mendatang yang penting.

Setiap individu mempunyai efikasi diri yang berbeda-beda pada situasi yang berbeda, tergantung kepada: 1) Kemampuan yang dituntut oleh situasi yang berbeda itu, 2) Kehadiran orang lain khususnya saingan, dan 3) Keadaan fisiologis dan emosional.

Efikasi yang tinggi atau rendah, dikombinasikan dengan lingkungan yang responsive atau tidak responsive akan menghasilkan empat kemungkinan prediksi tingkah laku (tabel 1).

Tabel 1. Kombinasi efikasi dengan lingkungan sebagai prediktor tingkah laku

\begin{tabular}{|c|c|c|}
\hline Efikasi & Lingkungan & Prediksi hasil tingkah laku \\
\hline Tinggi & Responsif & $\begin{array}{l}\text { Sukses, melaksanakan tugas yang sesuai dengan } \\
\text { kemampuannya }\end{array}$ \\
\hline Rendah & Tidak responsif & $\begin{array}{l}\text { Depresi, melihat orang lain sukses pada tugas yang } \\
\text { dianggapnya sulit }\end{array}$ \\
\hline Tinggi & Tidak responsif & $\begin{array}{l}\text { Berusaha keras mengubah lingkungan menjadi } \\
\text { responsive, melakukan protes, aktivitas sosial, } \\
\text { bahkan membuat perubahan }\end{array}$ \\
\hline Rendah & Responsif & Orang menjadi apatis, pasrah, merasa tidak mampu \\
\hline
\end{tabular}

\section{Lokus Kendali}

Menurut Robbins (2008: 138), Locus of control mengandung arti tingkat di mana individu yakin bahwa mereka adalah penentu nasib mereka sendiri. Menurut Rotter dalam Robbins (2008: 138), Locus of control mengandung arti sebagai tindakan dimana individu menghubungkan peristiwa-peristiwa dalam kehidupannya dengan tindakan atau kekuatan di luar kendalinya.

Jadi, locus of control adalah sikap seseorang yang meyakini bahwa apa yang terjadi dalam dirinya merupakan akibat dari tindakannya sendiri. Locus of control merupakan suatu konsep yang menuju pada keyakinan individu mengenai peristiwa yang terjadi dalam hidupnya. Locus of control menggambarkan seberapa jauh seseorang memandang hubungan antara perbuatan yang dilakukan (action) dengan akibat/hasil. Locus of control berhubungan dengan sikap kerja dan citra diri seseorang

Rotter dalam Robbins (2008: 140), membedakan Locus of control menjadi dua, yaitu: 1) Locus of control internal ; Internality (I). Adalah individu-individu yang yakin bahwa mereka merupakan pemegang kendali atas apa pun yang terjadi pada diri mereka. Hasil adalah dampak langsung dari tindakannya. 2) Locus of control Eksternal ; Powerful Others $(P)$ dan Chance $(C)$. Adalah individu-individu yang yakin bahwa apa pun yang terjadi pada diri mereka dikendalikan oleh kekuatan luar seperti keberuntungan atau kesempatan.

Locus of control merupakan suatu indikator evaluasi inti diri karena individu yang berpikir bahwa mereka kurang memiliki kendali atas hidup mereka cenderung kurang memiliki kepercayaan diri. Sedangkan keberhasilan seseorang disebabkan oleh Locus of Control yang berbeda, baik untuk sukses maupun gagal. Saat menghadapi kegagalan, kita dianjurkan untuk menyikapi sebagai hal yang labil. Yang terjadi bisa berlawanan. Ada yang menganggap keberhasilan disebabkan karena ekonomi bagus dan lain-lain. Dan ketika ia menghadapi kegagalan, ia menuduh faktor Internal sebagai penyebabnya. Sikap yang baik adalah yang menempatkan faktor internal dan faktor eksternal sebagai kedua faktor yang saling mendukung. Misalkan saat seseorang mendapat peringkat 1 maka hal itu bukanlah hadiah dari guru melainkan karena jerih payah, ketekunan dan kecerdasan yang dimiliki oleh orang tersebut. Locus of control 
memiliki pengertian yang lebih tinggi dari kepercayaan diri. Locus of control merupakan keyakinan yang mendalam bahwa jika seseorang berbuat hal yang positif maka semua hal yang akan kembali padanya juga positif. Seorang peserta didik yang memiliki lokus kendali dalam dirinya dapat tampak terlihat dari: 1) Tidak mudah terpengaruh oleh temannya, 2) Percaya akan kemampuan sendiri, 3) Tahu sampai sejauh mana kemampuan yang dimiliki, dan 4) Dominan menyendiri

\section{METODE}

Penelitian ini dilakukan di SMAN Reguler Kecamatan Ciracas, Jakarta timur. Penelitian ini dilaksanakan selama 4 bulan dari bulan April 2013 sampai Juli 2013. Penelitian ini merupakan penelitian kuantitatif menggunakan metode survey dengan analisis data menggunakan analisis jalur.

Desain penelitiannya dapat digambarkan sebagai berikut:

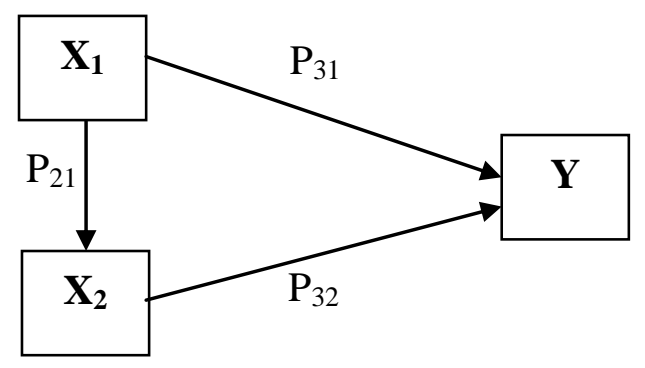

Gambar 1. Desain Penelitian

Keterangan:

$\mathrm{X}_{1}=$ Efikasi Diri

$\mathrm{X}_{2}=$ Lokus Kendali

$\mathrm{Y}=$ Prestasi Belajar Matematika

Teknik pengambilan sampel dilakukan melalui teknik proporsional cluster random sampling, dimana jumlah sampel dari setiap sekolah diambil secara proporsional berdasarkan perbandingan jumlah peserta didik setiap sekolah terhadap jumlah populasi keseluruhan. Dengan tekhnik ini ini maka diperoleh anggota sampel dari masing-masing sekolah sebagai berikut:

1. SMAN 64 Jakarta $=\frac{726}{1546} \times 100 \%=46,9 \approx 47$ orang

2. SMAN 105 Jakarta $=\frac{920}{1546} \times 100 \%=53,04 \approx 53$ orang

\section{HASIL DAN PEMBAHASAN}

\section{Deskripsi Data}

Tabel 2. Rangkuman Hasil Perhitungan Statistik Deskriptif

\begin{tabular}{lccc}
\hline Ukuran Deskriptif & $\begin{array}{c}\text { Efikasi Diri } \\
\left(\mathbf{X}_{\mathbf{1}}\right)\end{array}$ & $\begin{array}{c}\text { Lokus Kendali } \\
\left(\mathbf{X}_{\mathbf{2}}\right)\end{array}$ & $\begin{array}{c}\text { Prestasi Belajar } \\
\text { Matematika }(\mathbf{Y})\end{array}$ \\
\hline Mean & 80.7147 & 70.3566 & 71.1417 \\
Median & 81.9450 & 70.8400 & 75.0000 \\
Modus & 82.62 & 75.11 & 75.00 \\
Simpangan baku & 10.4479 & 8.04435 & 17.3674 \\
Varians & 109.159 & 64.712 & 301.627 \\
\hline
\end{tabular}




\section{Uji Persyaratan Data}

Uji persyaratan analisis data terdiri dari uji normalitas dan uji linieritas.

Tabel 3. Rangkuman Hasil Uji Normalitas

\begin{tabular}{lcc}
\hline \multicolumn{1}{c}{ Variabel } & Sig. & Simpulan \\
\hline Efikasi Diri $\left(\mathrm{X}_{1}\right)$ & 0.800 & Data berdistribusi normal \\
Lokus Kendali $\left.\mathrm{X}_{2}\right)$ & 0.183 & Data berdistribusi normal \\
Prestasi Belajar Matematika $(\mathrm{Y})$ & 0.150 & Data berdistribusi normal \\
\hline
\end{tabular}

Berdasarkan tabel 3 maka dapat disimpulkan bahwa data dari ketiga variabel penelitian menunjukan semua sampel lebih besar dari 0,05 sehingga $\mathrm{H}_{0}$ diterima. Dengan kata lain data dari semua sampel penelitian berdistribusi normal.

Tabel 4. Rangkuman Hasil Uji Linieritas

\begin{tabular}{ccc}
\hline Garis yang Diuji & Sig. & Simpulan \\
\hline $\mathrm{X}_{1}$ terhadap Y & 0.581 & Model garis regresi berpola linier \\
$\mathrm{X}_{2}$ terhadap Y & 0.761 & Model garis regresi berpola linier \\
$\mathrm{X}_{1}$ terhadap $\mathrm{X}_{2}$ & 0.468 & Model garis regresi berpola linier \\
\hline
\end{tabular}

Berdasarkan tabel 4 maka dapat disimpulkan bahwa data dari ketiga model garis regresi yang diuji menunjukan memiliki nilai Sig. $<0.05$ sehingga $\mathrm{H}_{0}$ diterima. Dengan kata lain semua model garis regresi yang diujia berpola linier.

\section{Pengujian Hipotesis}

Tabel 5. Rangkuman Hasil Analisis Regresi

\section{Coefficients $^{\mathrm{a}}$}

\begin{tabular}{|c|c|c|c|c|c|c|}
\hline & & \multicolumn{2}{|c|}{$\begin{array}{c}\text { Unstandardized } \\
\text { Coefficients }\end{array}$} & \multirow{2}{*}{$\begin{array}{c}\begin{array}{c}\text { Standardized } \\
\text { Coefficients }\end{array} \\
\text { Beta }\end{array}$} & \multirow[b]{2}{*}{$\mathrm{t}$} & \multirow[b]{2}{*}{ Sig. } \\
\hline \multicolumn{2}{|c|}{ Model } & B & Std. Error & & & \\
\hline 1 & (Constant) & $1.817 \mathrm{E}-6$ & .097 & & .000 & 1.00 \\
\hline & Efikasi Diri & .225 & .098 & .225 & 2.301 & .024 \\
\hline & Lokus Kendali & .182 & .098 & .182 & 1.855 & .06 \\
\hline
\end{tabular}

a. Dependent Variable: Prestasi Belajar Matematika

1. Pengujian dilakukan dari hasil koefisien jalur pada struktur 2, dengan persamaan:

$a+b_{31} X_{1}+b_{32} X_{2}$

Menguji signifikasi koefisien jalur:

$t_{h}=\frac{p_{31}}{s_{p 31}}=\frac{0,225}{0,0972}=2,3148$

Menentukan $\boldsymbol{t}_{\boldsymbol{t}}$ untuk $\alpha=0,05 \mathrm{dan} \mathrm{dk}=\mathrm{n}-\mathrm{k}-1=97$, maka didapat $\boldsymbol{t}_{\boldsymbol{t}}=1,98$ (uji dua pihak). Karena $\left|\mathbf{t}_{\mathbf{h}}\right|>\mathbf{t}_{\mathbf{t}}(2,3148>1,98)$, maka $\mathrm{H}_{0}$ ditolak dan disimpulkan terdapat pengaruh langsung yang signifikan efikasi diri terhadap prestasi belajar Matematika sesuai dengan hasil perhitungan SPSS yang didapatkan nilai $t_{\mathrm{h}}=2,031$ dengan sig. $=$ 0,024 (lihat Tabel 5). 
2. Pengujian dilakukan dari hasil koefisien jalur pada struktur 2, dengan persamaan:

$a+b_{31} X_{1}+b_{32} X_{2}$

Menguji signifikasi koefisien jalur:

$t_{h}=\frac{p_{32}}{s_{p 32}}=\frac{0,182}{0,0972}=1,8724$

Menentukan $\boldsymbol{t}_{\boldsymbol{t}}$ untuk $\alpha=0,05 \mathrm{dan} \mathrm{dk}=\mathrm{n}-\mathrm{k}-1=97$, maka didapat $\boldsymbol{t}_{\boldsymbol{t}}=1,98$ (uji dua pihak). Karena $\left|\mathbf{t}_{\mathbf{h}}\right|<\mathbf{t}_{\mathbf{t}}(1,8724<1,98)$, maka $\mathrm{H}_{0}$ diterima dan disimpulkan tidak terdapat pengaruh langsung yang signifikan lokus kendali terhadap prestasi belajar Matematika sesuai dengan hasil perhitungan SPSS yang didapatkan nilai $t_{h}=1,855$ dengan sig. $=0,067$ (lihat Tabel 5).

3. Pengujian dilakukan dari hasil koefisien jalur pada struktur 1, dengan persamaan:

$\hat{X}_{2}=a X_{1} \rightarrow \hat{X}=P_{21} X_{1}$

Menentukan nilai thitung:

$t_{h}=\frac{p_{21}}{s_{p 21}}=\frac{-0,0846}{0,101}=-0,8376$

Menentukan $\boldsymbol{t}_{\boldsymbol{t}}$ untuk $\alpha=0,05 \mathrm{dan} \mathrm{dk}=\mathrm{n}-\mathrm{k}-1=98$, maka didapat $\boldsymbol{t}_{\boldsymbol{t}}=1,98$ (uji dua pihak). Karena $\left|\mathbf{t}_{\mathbf{h}}\right|<\mathbf{t}_{\mathbf{t}}(0,8376<1,98)$, maka $\mathrm{H}_{0}$ diterima dan disimpulkan tidak terdapat pengaruh langsung yang signifikan efikasi diri terhadap lokus kendali.

4. Pengujian dilakukan dari hasil koefisien jalur pada struktur 2 dan 3 , dengan persamaan:

$\hat{X}_{2}=a+b_{1} X_{1}+b_{2} X_{2}$

Koefisien jalur $\mathrm{X}_{1}$ ke $\mathrm{Y}$ melalui $\mathrm{X}_{2}$, yaitu:

$\mathrm{p}_{321}=\mathrm{p}_{21} \times \mathrm{p}_{32}=-0,0846 \times 0,182=-0,01539$

Pengujian hipotesis

Maka diperoleh nilai $\mathbf{t}_{\mathbf{h}}$ yaitu:

$t_{h}=\frac{p_{321}}{s_{g}}=\frac{-0,01539}{0,099}=-0,1555$

Menentukan $\boldsymbol{t}_{\boldsymbol{t}}$ untuk $\alpha=0,05 \mathrm{dan} \mathrm{dk}=\mathrm{n}-\mathrm{k}-1=98$, maka didapat $\boldsymbol{t}_{\boldsymbol{t}}=1,98$ (uji dua pihak). Karena $\left|\mathbf{t}_{\mathbf{h}}\right|<\mathbf{t}_{\mathbf{t}}(0,1555<1,98)$, maka $\mathrm{H}_{0}$ diterima dan disimpulkan tidak terdapat pengaruh tidak langsung yang signifikan efikasi diri terhadap prestasi belajar Matematika melalui lokus kendali.

\section{Pembahasan}

Berpedoman pada data hasil analisis diketahui bahwa terdapat pengaruh langsung yang signifikan antara efikasi diri terhadap prestasi belajar Matematika. Oleh karena itu untuk meningkatkan dan mengoptimalkan prestasi belajar peserta didik salah satunya adalah dengan meningkatkan efikasi diri peserta didik. Untuk meningkatkan efikasi diri peserta didik perlu didukung oleh peningkatan hubungan antara guru, teman sejawat, keluarga dan lingkungan. Sesuai dengan pendapat Alwisol (2009: 288), "prestasi yang pernah dicapai masa lalu adalah pengalaman performansi. Sebagai sumber, performansi masa lalu menjadi pengubah efikasi diri yang paling kuat penngaruhnya. Prestasi yang bagus meningkatkan ekspektasi efikasi sedangkan kegagalan akan menurunkan efikasi diri". 
Penguasaan yang sempurna terhadap suatu mata pelajaran, memerlukan pencurahan perhatian yang rinci. Lokus kendali yang telah disadari dimiliki oleh peserta didik, mungkin sekali akan menjaga pikiran siswa, sehingga dia dapat menguasai pelajarannya. Bahkan jika tidak mengetahui betul atau kurang jelas akan dengan sigap untuk mencari tahu jawabannya walau harus dengan bertanya kepada guru atau teman. Pada gilirannya, meningkatkan prestasinya, juga semakin meningkat pula lokus kendali yang dimiliki.

Berbagai hal yang dapat dengan mudah diamati dari seorang anak yang memiliki efikasi diri tinggi adalah dengan: 1) Memiliki kepercayaan diri lebih tinggi dibanding teman-temannya, 2) Mempelajari materi yang belum dipelajari tanpa diperintah oleh guru, 3) Memiliki keingintahuan yang tinggi, 4) Tidak malu untuk bertanya, dan 5) Memiliki banyak cara untuk menyelesaikan suatu masalah atau soal.

Dengan berbagai hal yang telah dibahas pada bab sebelumnya maka hal-hal yang dapat dilakukan oleh guru untuk meningkatkan efikasi diri peserta didik adalah: 1) Memberikan penguatan atau retensi dalam hal ini pujian atau penghargaan dalam setiap hal yang mampu diselesaikan oleh peserta didik, 2) Memancing peserta didik untuk bertanya dan tidak menyalahkan apapun pendapat peserta didik, 3) Memberikan motivasi dengan pendekatan perorangan baik didalam kelas atau diluar kelas, dan 4) Mengkonsultasikan dengan guru konseling di sekolah untuk melakukan pendekatan individu (kerja sama seluruh warga sekolah).

Temuan penelitian menunjukkan bahwa tidak terdapat pengaruh tidak langsung dan signifikan efikasi diri terhadap prestasi belajar matematika peserta didik melalui lokus kendali. Berdasarkan temuan ini menunjukkan bahwa peningkatan prestasi belajar tidak dapat dilakukan dengan melalui peningkatan lokus kendali. Dengan membandingkan temuan yang lain dalam penelitian ini, menunjukkan bahwa peningkatan prestasi belajar matematika peserta didik oleh lokus kendali melalui peningkatan efikasi diri lebih tinggi daripada langsung dari lokus kendali.

Hal ini menunjukkan bahwa patut diduga bahwa akan lebih efektif meningkatkan prestasi belajar matematika jika dilakukan dengan membangkitkan efikasi diri terlebih dahulu kemudian meningkatkan lokus kendali peserta didik. Sehingga peserta didik memiliki keyakinan bahwa dia dapat memahami maupun menguasai mata pelajaran matematika. Dengan tumbuhnya efikasi diri maka peserta didik akan mencurahkan perhatiaannya secara penuh dan lokus kendali yang dimiliki akan mengontrol peserta didik dari segala sesuatu yang dapat membawa pengaruh negatif.

\section{PENUTUP}

\section{Simpulan}

bahwa:

Berdasarkan data hasil penelitian dan pembahasan, maka dapat disimpulkan

1. Terdapat pengaruh langsung yang signifikan efikasi diri terhadap prestasi belajar matematika.

2. Tidak terdapat pengaruh langsung yang signifikan lokus kendali (locus of control) terhadap prestasi belajar matematika.

3. Tidak terdapat pengaruh langsung yang signifikan efikasi diri terhadap lokus kendali (Locus of control).

4. Tidak terdapat pengaruh tidak langsung yang signifikan Efikasi diri terhadap prestasi belajar matematika melalui lokus kendali (locus of control).

\section{Saran}

Berdasarkan temuan penelitian di atas maka peneliti menyarankan: 
1. Guru harus senantiasa meningkatkan potensi yang dimiliki oleh peserta didik khususnya aspek efikasi diri dan lokus kendali sehingga prestasi belajar matematikanya akan meningkat pula.

2. Kepala sekolah sebagai supervisor harus dapat meningkatkan kinerja profesional guru, hubungan guru dan peserta didik, sesama peserta didik dan lingkungan sekolah.

\section{DAFTAR PUSTAKA}

Alisah, Evawati. 2007. Filsafat Dunia Matematika. Jakata: Prestasi Pustaka.

Alwisol . 2009. Psikologi Kepribadian. Malang: UMM Press.

Chaplin, P.J. 2002. Kamus Lengkap Psikologi. Diterjemahkan oleh: Kartini Kartono. Jakarta: Raja Grafindo Persada.

Djamarah, Syaiful Bahri. 2001. Anak Didik dari Interaksi Edukatif. Jakarta: Rineka Cipta.

Mulyana, E. 2006. mplementasi Kurikulum 2004: Panduan Belajar KBK. Bandung: Remaja Rosdakarya.

Robbbins dan Judge. 2008. Perilaku Organisasi, Jakarta: Salemba Empat.

Slameto. 2003. Belajar dan Faktor-faktor yang Mempengaruhinya. Cetakan 4 Bandung: Rineka Cipta.

Sudjana, Nana. 1999. Dasar-Dasar Proses Belajar Mengajar. Bandung: Sinar Baru.

Syah, Muhibbin. 2005. Psikologi Pendidikan dengan Pendidikan Baru. Bandung: Rosdakarya. 